\title{
Congenital Hypoplastic Anemia, Diabetes, and Severe Renal Tubular Dysfunction Associated with a Mitochondrial DNA Deletion
}

\author{
ANNA MAJANDER, ANU SUOMALAINEN, KIM VETTENRANTA, HANNU SARIOLA, \\ MIKKO PERKKIÖ, CHRISTER HOLMBERG, AND HELENA PIHKO \\ Department of Medical Chemistry [A.M.] and the Children's Hospital, University of Helsinki [K.V., H.S., C.H.. \\ H.P.J) Laboratory of Molecular Genetics, National Public Health Institute [A.S.]; and the Children's Hospital. \\ University of Kuopio [M.P.J, Finland
}

\begin{abstract}
Mitochondrial DNA (mtDNA) deletion is associated with a variety of clinical entities. In addition to progressive external ophthalmoplegia and Kearns-Sayre syndrome, mtDNA deletions have been demonstrated in Pearson's syndrome. We report an mtDNA deletion in an infant with a variant of Pearson's syndrome. Not only does she have congenital anemia, severe tubulopathy, and exocrine pancreas insufficiency, but she also has diabetes and cerebral atrophy. However, there are no signs of gut or liver involvement. Bone marrow improved while new tissues were involved, thus showing variability in progression of the disease. Decreased respiratory chain enzyme activities were demonstrated in muscle, and an mtDNA deletion was demonstrated in muscle, kidney, leukocytes, and fibroblasts. (Pediatr Res 30: 327-330, 1991)
\end{abstract}

Abbreviations

cyt c, cytochrome c

KSS, Kearns-Sayre syndrome

mtDNA, mitochondrial DNA

$\mathrm{PCR}$, polymerase chain reaction

Mitochondrial dysfunction has been described in a heterogeneous group of clinical entities varying from benign ocular myopathy to fatal encephalomyopathy and multisystem disorders of organs with a high energy demand. Typically, "raggedred-fibers" are found in modified Gomori-trichrome stained muscle biopsies and abnormal mitochondria in electron microscopy of affected tissues. Defects are demonstrated in several biochemical pathways of energy production, most frequently in the mitochondrial respiratory chain enzymes, which are encoded both by nuclear and mitochondrial genes. A large deletion of human mtDNA in patients with mitochondrial myopathies was first described by Holt et al. (1). This has led to new possibilities in diagnosing and classifying mitochondrial diseases. Deletions have been found in patients with progressive external ophthalmoplegia (2) and $\operatorname{KSS}(3,4)$. In addition to these clinical entities, deletions have been reported in one patient with pancytopenia (5) and in Pearson's syndrome $(6,7)$. We now report a 2 -yr-old child with severe renal tubular dysfunction, pancreatic insufficiency, diabetes, cerebral atrophy, and recovery from congenital

Received January 3, 1991; accepted May 30, 1991.

Correspondence and reprint requests: Dr. Helena Pihko, Children's Hospital, University of Helsinki, Stenbäckinkatu il, SF-00290 Heisinki, Finland.

Supported by the Arvo and Lea Ylppö Foundation and the Sigrid Juselius Foundation. hypoplastic anemia (a multisystem disease with an mtDNA deletion).

\section{CASE REPORT}

This 28-mo-old girl is the first child of healthy, nonrelated parents. The pregnancy was uneventful except for a mild polyhydramnios. She was born after 38 wk of gestation with a weight of $2400 \mathrm{~g}$ and a macrocytic, normochromic anemia, a low reticulocyte count, and considerable aniso- and poikilocytosis. Her lowest $\mathrm{Hb}$ level was $56 \mathrm{~g} / \mathrm{L}$, reticulocytes $0.5 \%$, leucocytes $4.6 \times 10^{9} / \mathrm{L}(11 \%$ granulocytes $)$, and thrombocytes $73 \times 10^{\circ} / \mathrm{L}$, respectively. The bone marrow was hypoplastic, but without signs of dyserythropoiesis or malignancy. Screening for intrauterine infections was negative. Ringed sideroblasts and vacuolization of myeloid precursors were seen in the bone marrow.

At $2 \mathrm{mo}$, oral prednisolone $(2 \mathrm{mg} / \mathrm{kg} / \mathrm{d})$ was started. It was discontinued after $12 \mathrm{~d}$ when the child developed diabetes mellitus, which was treated with insulin for $3 \mathrm{wk}$. Anemia with reticulocytopenia, granulocytopenia, and thrombocytopenia persisted, and at $3.5 \mathrm{mo}$ cyclosporin was started $(10-30 \mathrm{mg} / \mathrm{kg} / \mathrm{d})$. Blood specific cyclosporin concentration was $115-290 \mu \mathrm{g} / \mathrm{L}$ (Cyclotrac; Ingstar, Stillwater, MO). Signs of bone marrow recovery were seen at $7.5 \mathrm{mo}$. At $10 \mathrm{mo}$, diabetes mellitus redeveloped and cyclosporin was discontinued.

Up to the age of $1.2 \mathrm{yr}$, her height was $3 \mathrm{SD}$ below the mean, then her growth ceased. Her peak weight was $30 \%$ above the mean at 6 mo but decreased to $35 \%$ below the mean by $2 \mathrm{yr}$.

At $17 \mathrm{mo}$, polyuria $(14 \mathrm{~mL} / \mathrm{kg} / \mathrm{h})$ was noticed. There was a metabolic acidosis (arterial blood pH 7.15, base excess -19.4 $\mathrm{mmol} / \mathrm{L}$, standard bicarbonate $9.5 \mathrm{mmol} / \mathrm{L}$, urine $\mathrm{pH} 5.0$ ), hypophosphatemia $(0.3 \mathrm{mmol} / \mathrm{L})$, hypocalcemia $(1.6 \mathrm{mmol} / \mathrm{L})$, hypomagnesemia $(0.5 \mathrm{mmol} / \mathrm{L})$, hyponatremia $(124 \mathrm{mmol} / \mathrm{L})$, hypokalemia $(2.5 \mathrm{mmol} / \mathrm{L})$, glucosuria, and a generalized aminoaciduria with normal plasma amino acids. The polyuria was unresponsive to desmopressin. Alkali, phosphate, dihydrotachysterol, calcium, and magnesium supplementation were started.

On admission to our institution at $20 \mathrm{mo}$, she was hypotonic with delayed motor development, but without ataxia. She had lost her ability to walk but was able to sit and stand unsupported. The tendon reflexes as well as cranial nerve functions were normal. Her hearing was normal and she could speak a few words. Although easily fatigued, she was mentally alert. Electroencephalography showed mild general background slowing, and a cranial computed tomography scan showed marked cerebral atrophy. There were no signs of polyneuropathy on electroneuromyography and the ophthalmologic examination was normal. Blood lactate was $4.5 \mathrm{mmol} / \mathrm{L}$ (normal value $<1.6 \mathrm{mmol} / \mathrm{L}$ ) and pyruvate was $100 \mu \mathrm{mol} / \mathrm{L}$ (normal value $<68 \mu \mathrm{mol} / \mathrm{L}$ ) (lactate:pyruvate 44). Cerebrospinal fluid lactate was $6.6 \mathrm{mmol} /$ 
$\mathrm{L}$ (normal value $<2.7 \mathrm{mmol} / \mathrm{L}$ ) and cerebrospinal fluid protein concentration was $465 \mathrm{mg} / \mathrm{L}$ (normal value $<400 \mathrm{mg} / \mathrm{L}$ ).

There was a macrocytic, normochromic anemia with a positive erythrocyte i-antigen. Reticulocytes were $1.4-4.0 \%$ and fetal $\mathrm{Hb}$ $16 \%$, and thrombocytes and leucocytes were normal. The bone marrow was normocellular with a striking vacuolization of nonerythroid precursors.

Liver function tests, ultrasound examination of the liver, chest $\mathrm{x}$-ray and echocardiography were normal. However, the levels of C-peptide and pancreatic amylase in the serum were immeasurable, and stool fat excretion was increased.

The kidneys were enlarged, with increased echodensity on ultrasound examination. Blood pressure was 97-158/60-103 $\mathrm{mm} \mathrm{Hg}$, serum creatinine, 34-64 $\mu \mathrm{mol} / \mathrm{L}$, and glomerular filtration rate, $37 \mathrm{~mL} / \mathrm{min} / 1.73 \mathrm{~m}^{2}$. The urinary volume was $11-16$ $\mathrm{mL} / \mathrm{kg} / \mathrm{h}$, with proteinuria, glucosuria, and generalized aminoaciduria but no hematuria. Fractional excretion of sodium and phosphate increased to 0.03 and 1.5 , respectively. Urinary phosphate excretion and phosphate clearance were high (64 $\mu \mathrm{mol} / \mathrm{min} / 1.73 \mathrm{~m}^{2}$ and $103 \mathrm{~mL} / \mathrm{min} / 1.73 \mathrm{~m}^{2}$, respectively). Blood standard bicarbonate was $9-17 \mathrm{mmol} / \mathrm{L}$ with a urinary $\mathrm{pH}$ of $5.0-8.5$.

Potassium, calcium, magnesium, phosphate, bicarbonate (30 $\mathrm{mmol} / \mathrm{kg} / \mathrm{d}$ ), dihydrotachysterol, and carnitine supplementation normalized her respective serum concentrations except serum bicarbonate $(10-16 \mathrm{mmol} / \mathrm{L})$. Insulin and pancreatic enzyme supplementation were used. After exclusion of more common causes of severe renal tubular dysfunction, a respiratory chain defect was suspected.

At $34 \mathrm{mo}$, the patient remains an outpatient with nearly normal blood count (Hb $116 \mathrm{~g} / \mathrm{L}$, fetal-Hb $4.6 \%$, mean corpuscular volume $95 \mathrm{fL}$, and thrombocytes $434 \times 10^{9} / \mathrm{L}$ ), normal electrolytes, serum bicarbonate $10-18 \mathrm{mmol} / \mathrm{L}$, blood lactate 2.6 $\mathrm{mmol} / \mathrm{L}$, and pyruvate $148 \mu \mathrm{mol} / \mathrm{L}$, an immeasurable level of serum C-peptide, normal serum phosphate, and generalized aminoaciduria. Treatment with indomethacin $(3 \mathrm{mg} / \mathrm{kg} / \mathrm{d})$ reduced her diuresis from $12 \mathrm{~mL} / \mathrm{kg} / \mathrm{h}$ to $5-6 \mathrm{~mL} / \mathrm{kg} / \mathrm{h}$ and normalized her serum phosphate transiently. Presumably because of her malnutrition and hypoproteinemia, this resulted in edema. The medication had to be discontinued because of intestinal bleeding. Subsequently, her urinary volume has normalized. She has not grown and has severe muscle wasting, but is mentally alert. Renal transplantation was discussed but rejected because of her poor general condition and the multisystemic nature of her disease. Her renal dysfunction has not progressed recently.

\section{MATERIALS AND METHODS}

A kidney biopsy specimen was fixed for light and electron microscopy in phosphate-buffered $10 \%$ formalin and phosphatebuffered $2.5 \%$ glutaraldehyde, respectively. The paraffin-embedded sample was stained with hematoxylin-eosin, modified Masson-Trichrome, van Gieson, and periodic acid-Schiff. For electron microscopy, the sample was postfixed with $1 \%$ osmium tetroxide and stained with uranyl acetate and lead citrate. For immunofluorescence, the sample was frozen in liquid nitrogen, cut at $7 \mu \mathrm{m}$, and stained by antibodies against immunoglobulins, complement factor 3 , complement factor 1q, and fibrin.

Oxygen consumption of isolated muscle mitochondria was measured polarographically $(8,9)$. The activities of respiratory chain enzymes [rotenone-sensitive NADH coenzyme Q reductase (10), rotenone-sensitive NADH cyt $c$ reductase (11), antimycin A-sensitive succinate cyt $c$ reductase (12), cyanide sensitive ferrocytochrome c oxidase (13) and citrate synthase (14)] were assayed spectrophotometrically from a sonicated mitochondrial preparation, as previously described (10-14). As controls, we used diagnostic muscle biopsies showing no morphologic abnormalities from patients who were eventually considered unaffected by muscle diseases.

A culture of fibroblasts was established from a skin biopsy.
Cells were harvested for the isolation of total DNA after six passages.

Total DNA was prepared from $40 \mathrm{mg}$ of a muscle biopsy sample, from leukocytes and cultured fibroblasts as previously described (15). After the histologic analysis, the remaining kidney needle biopsy sample was incubated in proteinase $\mathrm{K}$ and directly subjected to PCR. Primers and conditions will be described ahead. Ten micrograms of DNA were digested with restriction enzyme $P v u \mathrm{II}$, electrophoresed through $0.6 \%$ agarose gel, and transferred to nylon filters (Hybond-N, Amersham, Buckinghamshire, UK), according to Southern (16). Hybridization was carried out with the probe (total mouse mtDNA, courtesy of Dr. Per Sunnerhagen, University of Gothenburg, Sweden) labeled with ${ }^{32} \mathrm{P}$ to a sp act of $10^{9} \mathrm{dpm} / \mu \mathrm{g}$ using primer extension reaction (17) (Random primer DNA labeling kit; Boehringer Mannheim, Germany) followed by overnight exposure to Kodak X-Omat AR film a $-70^{\circ} \mathrm{C}$. Further analysis was carried out by hybridizing the filters with short cloned fragments of human mtDNA provided by Dr. Nils-Göran Larsson (University of Gothenburg, Sweden). The probes covered the regions of mtDNA map positions (18) 8.287 to 8.587 (K 10) and 8.729 to 10.254 (K12). After the approximate localization of the deletion, specific oligonucleotide primers were synthesized to flank the suspected deletion breakpoints so that they contained the restriction sites of restriction endonucleases XbaI (map location 8.289) and TaqI (map location 14.967). PCR was carried out with $100 \mathrm{ng}$ of template DNA and two units of Taq-polymerase (Perkin-Elmer Cetus, Norwalk, CT), using 25 cycles of $94^{\circ} \mathrm{C}$ for $1 \mathrm{~min}, 55^{\circ} \mathrm{C}$ for $2 \mathrm{~min}$, and $72^{\circ} \mathrm{C}$ for $2 \mathrm{~min}$ on an automated thermal cycler (PerkinElmer Cetus).

\section{RESULTS}

The renal biopsy showed tubular dilation in conjunction with degenerative changes in the tubular epithelium but not immunofluorescence for immunoglobulins, complement factor 3, complement factor 1q, or fibrin. Electron microscopy revealed enlarged mitochondria (Fig. 1).

Biochemical analysis of muscle mitochondria showed a general respiratory chain defect (Table 1). Oxygen consumption was decreased with all tested substrates, suggesting cyt $c$ oxidase deficiency. No respiratory control was observed. Of the respiratory chain enzymes, complex I was most severely affected (25$37 \%$ of control values), and the others were $50-70 \%$ of control.

Genomic Southern blot analyses demonstrated two different populations of mtDNA in muscle, leukocytes, and fibroblasts (Fig. 2). The hybridizing band of $16.5 \mathrm{~kb}$ corresponded to the normal-sized mtDNA and that of approximately $10.5 \mathrm{~kb}$ corresponded to the deleted population of mtDNA. In muscle, the

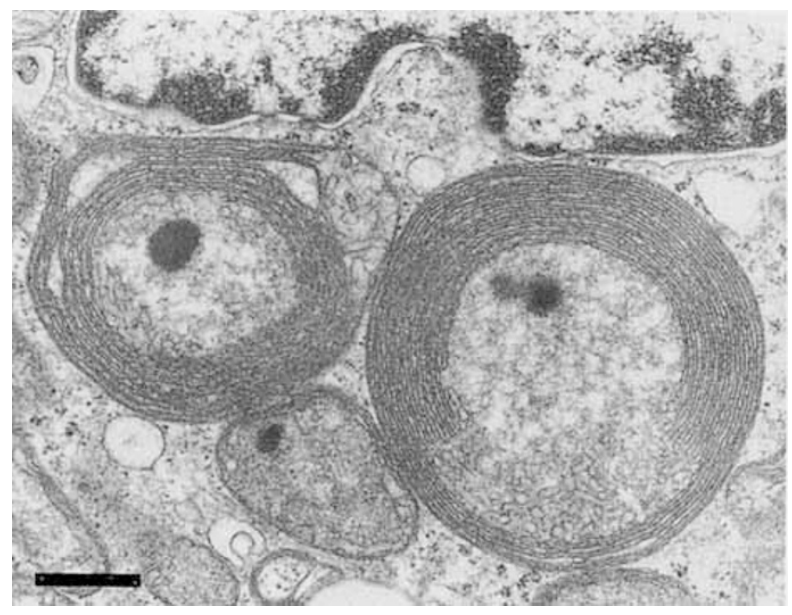

Fig. 1. Electron microscopy. Giant mitochondria in proximal tubules of the kidney biopsy. Magnification $\times 15000$, bar $=500 \mathrm{~nm}$. 
Table 1. Enzyme activities in isolated muscle mitochondria

\begin{tabular}{lrc}
\hline & Patient & Controls* \\
\hline Polarographic activities $\dagger$ & & \\
$\quad$ RCR & 1.0 & $3.5 \pm 1.8(26)$ \\
Pyruvate + malate & 11.9 & $60 \pm 24(21)$ \\
Succinate + rotenone & 12.5 & $65 \pm 24(26)$ \\
$\quad$ Ascorbate + TMPD & 122.6 & $338 \pm 140(27)$ \\
Spectrophotometric activities $\$$ & & \\
$\quad$ Citrate synthase & 504.2 & $836 \pm 270(31)$ \\
NADH:DB reductase & 32.1 & $86 \pm 27(21)$ \\
NADH:cyt c reductase & 76.2 & $299 \pm 93(23)$ \\
Succinate:cyt c reductase & 108.9 & $225 \pm 69(27)$ \\
Cyto c oxidase & & \\
$\quad 50 \mu \mathrm{M}$ ferrocyt c & 574.6 & $1149 \pm 286(31)$ \\
$100 \mu \mathrm{M}$ ferrocyt c & 1061.7 & $1547 \pm 479(36)$ \\
\hline
\end{tabular}

* Control values are mean \pm SD; number of controls in parentheses.

$\uparrow$ Polarographic activities correspond to oxygen consumption ( $\mathrm{nmol}$ $\mathrm{O} / \mathrm{min} / \mathrm{mg}$ mitochondrial protein). RCR, respiratory control ratio: TMPD, tetramethyl-p-phenylenediamine.

$\ddagger$ Spectrophotometric activities correspond to cyto $c$ reduced or oxidized, n-decyl coenzyme Q (DB) reduced and citrate formed, expressed as $\mathrm{nmol} / \mathrm{min} \mathrm{mg}$ mitochondrial protein.

deleted population corresponded to $80 \%$ of total mtDNA estimated from densitometry of autoradiography, in leukocytes $75 \%$, and in fibroblasts $35 \%$, respectively. In the further hybridizations, the deletion population hybridized with the probe $\mathrm{K} 10$, but not with $\mathrm{K} 12$, indicating the upstream deletion breakpoint to be between the map positions 8.300 and 8.800 . The PCR reaction product of $1.070 \mathrm{~kb}$ localized the other breakpoint between 13.900 and 14.300 , corresponding to a deletion of approximately $5.7 \mathrm{~kb}$. Because of the small size of the kidney biopsy available, PCR reaction with overall described primers was used, and the deletion was confirmed to exist also in kidney. The deleted region contained genes encoding subunit 6 of ATPase, subunit 3 of cyt c oxidase, and subunits $3,4,4 \mathrm{~L}$, and 5 of $\mathrm{NADH}$-dehydrogenase complex, as well as five transfer RNA genes.

\section{DISCUSSION}

The infant described here presents a mtDNA deletion with a progressive clinical involvement, first affecting bone marrow, then pancreas, cerebrum, and kidneys. With this combination of organs involved, she most likely belongs to the group of Pearson's marrow-pancreas syndrome, which has recently been included in the mitochondrial disorders because of demonstrating mutations in mtDNA $(6,7)$.

In contrast to reported cases of Pearson's syndrome, our patient does not have any signs of liver or gut involvement. Furthermore, she shows spontaneous bone marrow recovery from congenital hypoplastic anemia. Her predominant symptom is severe renal tubular dysfunction, which has previously been associated with other mitochondrial disorders like Leigh syndrome (19), mitochondrial myopathy (20-22), $\operatorname{KSS}(23,24)$, and also Pearson's syndrome (7). Although her tubular dysfunction has not recently progressed, it is presumably the main reason for her poor general condition. Exocrine pancreatic insufficiency is a well-known symptom of Pearson's syndrome. However, none of the previously reported patients had diabetes mellitus like our patient has. Nor does she have any clinical symptoms of encephalopathy, despite the severe cerebral atrophy seen in her computed tomography scan. Such neuroradiologic changes have not previously been reported in Pearson's syndrome.

Heteroplasmy of mtDNA was demonstrated in muscle, leukocytes, and cultured skin fibroblasts, with the deleted population corresponding to 80,75 , and $35 \%$ of total mtDNA, respectively. The mapping of the deletion showed it to be slightly larger than the previously reported $5.0-\mathrm{kb}$ "common deletion" of the same region (25). The deletion was confirmed to exist also in

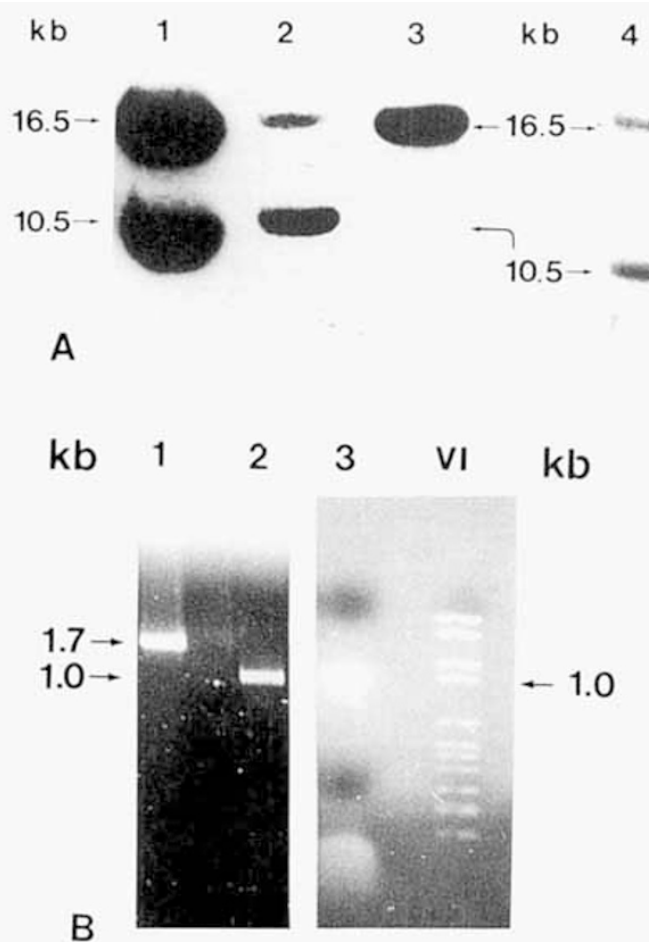

Fig. 2. A, Southern analysis. Lane 1, the patient, fibroblast DNA Lane 2, the patient. muscle DNA. Lane 3, control, healthy person, muscle DNA. Lane 4, the patient, blood DNA. Using mtDNA as probe. two hybridizing bands were seen in the lanes 1,2 , and 4 . Note a band at $10.5 \mathrm{~kb}$ corresponding to the more rapidly migrating mtDNA population due to a deletion of $5.7 \mathrm{~kb}$. The sizes were calculated on the basis of bacteriophage lambda digested with $H$ indIII as a marker. $B$, The size of the mtDNA deletion of the patient as well as its presence in her kidney tissue was confirmed using PCR. The distance of the primers Xba8.2 and Taq14.9 (see text) was $6.7 \mathrm{~kb}$, which was too far to be amplified from the wild type mtDNA population. In the case of a deletion between primers, the small fragment was amplified efficiently and the size of the deletion was counted from the resulting fragment. In the PCR, the following fragments were detected. Lane 1 , a control patient with progressive external ophthalmoplegia showing a "common deletion" of 5.0 $\mathrm{kb}$ that results in a fragment of $1.7 \mathrm{~kb}$. Lane 2, muscle mtDNA of our patient; lane 3, Kidney mtDNA of our patient, a fragment of $1.0 \mathrm{~kb}$ corresponding to a deletion of $5.7 \mathrm{~kb}$. The molecular weight marker VI (Boehringer Mannheim) was pBR328 DNA cut with Bgll and IIindl (fragment sizes $2.167 .1 .766,1.230,1.033,653 \mathrm{bp}$, elc.).

kidney by PCR. The activities of respiratory chain enzymes in muscle mitochondria were generally decreased, corresponding to the mutation in mtDNA, which encodes several subunits of respiratory chain enzymes. Enlarged mitochondria were demonstrated in the renal tubular cells.

The clinical presentation of mtDNA deletion has mostly been progressive external ophthalmoplegia. KSS, and, in a few cases, Pearson's syndrome. Each of these three entities appears with a distinct clinical picture and age of onset independent of the site of the deletion. However, the recent knowledge of these disorders indicates considerable overlapping between these groups, and even progression from one to another $(26,27)$. Phenotypic variability has been explained by differential tissue distribution of mutant mtDNA molecules during cell divisions in early embryonic development (28). The percentage of mutated mtDNA and tissue dependence on aerobic energy production together determine whether the tissue is clinically affected or not. The usual progression of the disease is gradual worsening of the symptoms and involvement of new tissues, which may be due to more rapid replication of deleted mtDNA molecules, leading to an increased percentage (26). The patient reported here demonstrates a variant of clinical expression and progression with 
gradual bone marrow recovery and simultaneous involvement of new tissues. It would have been interesting to study this recovery phenomenon on the molecular level. Nevertheless, her bone marrow disease is similar to cases recently reported by Larsson et al. (26) and McShane et al. (27), who recovered from sideroblastic anemia and later developed KSS. It remains to be seen whether our patient also develops typical symptoms of KSS. Therefore, not only genotype and phenotype but also progression show variability in mitochondrial diseases.

Diagnosis of the heterogeneous group of mitochondrial disorders requires not only careful analyses of histopathology and biochemistry, but also recently developed molecular genetic approaches. A large mtDNA deletion is reasonably simple to analyze from small tissue samples. Such an analysis could well be initiated with even a slight suspicion of mitochondrial disease, which apparently is an expanding group of highly diverse diseases. Our patient originally came to our institution for evaluation of kidney transplantation because of her severe tubular dysfunction. The multisystemic symptoms from bone marrow, pancreas, and cerebrum led us to suspect a mitochondrial origin for her disease, and an mtDNA deletion was demonstrated.

\section{REFERENCES}

1. Holt IJ, Harding AE, Morgan-Hughes JA 1988 Deletions of muscle mitochondrial DNA in patients with mitochondrial myopathies. Nature 331:717-719

2. Ozawa T, Yonela M. Tanaka M. Ohno K. Sato W, Suzuki H, Nishikimi M Yamamoto M. Nonaka I, Horai S 1988 Maternal inheritance of deleted mitochondrial DNA in a family with mitochondrial myopathy. Biochem Biophys Res Commun 154:1240-1247

3. Lestienne P, Ponsot GV 1988 Kearns-Sayre syndrome with muscle mitochondrial DNA deletion. Lancet 1:885

4. Zeviani M. Moraes CT, DiMauro S, Nakase H, Bonilla E, Schon EA, Rowland LP 1988 Deletions of mitochondrial DNA in Kearns-Sayre syndrome. Neurology 38:1339-1346

5. Rötig A, Colonna M, Blanche S. Fischer A. LeDeist F, Frezal J, Saudubray JM, Munnich A 1988 Deletion of blood mitochondrial DNA in pancytopenia. Lancet 2:567-568

6. Rötig A, Colonna M, Bonnefont JP, Blanche S. Fischer A. Saudubray JM, Munnich A 1989 Mitochondrial DNA deletion in Pearson's marrow/pancreas syndrome. Lancet 1:902-903

7. Rötig A, Cormier V. Blanche S, Bonnefont JP. Ledeist F. Romero N, Schmitz J, Rustin P, Fischer A, Saudubray JM, Munnich A 1990 Pearson's marrowpancreas syndrome a multisystem mitochondrial disorder in infancy. J Clin pancreas syndrome a $86: 1601-1608$

8. Bookelam H, Trijbels JMF, Sengers RCA, Jansson AJM, Veerkamp JH, Stadhouders AM 1978 Pyruvate oxidation in rat and human skeletal muscle mitochondria. Biochem Med 20:395-403

9. Estabrook RW 1967 Mitochondrial respiratory control and the polarographic measurement of ADP:O ratios. In: Estabrook RW, Pullman ME (eds) Methods in Enzymology, Vol 10. Academic Press, New York, pp 41-47

10. Wallace DC, Zheng X, Lott MT, Schoffner JM, Hodge JA, Kelley RI, Epstein CM, Hopkins LC 1988 Familial mitochondrial encephalomyopathy (MERFF): genetic, pathophysiological, and biochemical characterization of a mitochondrial DNA disease. Cell 55:601-610
11. Fischer JC, Ruitenbeek W, Trijbels JMF, Veerkamp JH, Stadhouders AM, Sengers RCA Janssen AJM 1986 Estimation of NADH oxidation in human skcletal muscle mitochondria. Clin Chim Acta 55:264-274

12. Fischer JC, Ruitenbeek W, Berden JA, Trijbels JMF, Veerkamp JH, Stadhouders AM. Sengers RCA. Janssen AJM 1985 Differential investigation of the capacity succinate oxidation in human skeletal muscle. Clin Chim Acta 153:23-36

13. Warton DC. Tzagoloff A 1967 Cytochrome oxidase from beef heart mitochondria. In: Estabrook RW. Pullman ME (eds) Methods in Enzymology, Vol 10. Academic press, New York. pp 245-250

14. Robinson JB, Brent LG. Sumegi B. Spere PA 1987 An enzymatic approach to the study of the Krebs tricarboxylic acid cycle. In: Darley-Usmar VM Rickwood D, Wilson MT (eds) Mitochondria, a Practical Approach. IRL Press Limited, Oxford. pp 160-161

15. Davis LG, Dibner MD, Battey JF 1986 Basic Methods in Molecular Biology. Elsevier, New York, pp 47-50

16. Southern EM 1975 Detection of specific sequences among DNA fragments separated by gel electrophoresis. J Mol Biol 98:503-515

17. Feinberg AP, Vogelstein B 1984 A technique for radiolabelling restriction endonuclease fragments to high specific activity. Anal Biochem 137:266267

18. Anderson S, Bankies AT, Barrell BG, de Bruijn MHL, Coulson AR, Drouin J, Eperon IC, Nierlich DP, Roe BA, Sanger F, Schreier PH. Smith AJM. Steden R. Young IG 1981 Sequence and organization of the human mitochondrial genome. Nature 290:457-465

19. Ogier H, Lombes A, Scholte HR, Poll-The BT, Fardeau M, Alcardi J, Vignes B, Niaudet P. Saudubray JM 1988 De Toni-Fanconi-Debre syndrome with Leigh syndrome revealing severe muscle cytochrome $c$ oxidase deficiency. J Pediatr 112:734-739

20. Van Biervliet JBGM, Bruinvis L, Ketting D, de Brec PK, van der Heiden C. Wadman SK 1977 Hereditary mitochondrial myopathy with lactic acidemia, a de Toni-Fanconi-Debre syndrome, and a defective respiratory chain in voluntary striated muscles. Pediatr Res 11:1088-1090

21. Zeviani M. Nonaka I. Bonilla E, Okino E, Moggio M, Jones S, DiMauro S 1985 Fatal infantile mitochondrial myopathy and renal dysfunction caused by cytochrome oxidase deficiency: immunological study in a new patient. Ann Neurol 17:414-417

22. Sperl W, Ruitenbeek W, Trijbels JMF, Sengers RCA, Stadhouders AM, Guggenbichler JP 1988 Mitochondrial myopathy with lactic acidemia, Fanconide Toni-Debre syndrome and a disturbed succinate:cytochrome c oxidoreductase activity. Eur J Pediatr 147:418-421

23. Goto Y, Itami N. Kajii N, Tochimaru H. Endo M, Horai S 1990 Renal tubular involvement mimicking Bartter syndrome in a patient with Kearns-Sayre syndrome. J Pediatr 116:904-910

24. Eviator L, Shanske S, Gauthier B. Abrams C, Maytal J, Slavin M, Valderrama E, DiMauro S 1990 Kearns-Sayre syndrome presenting as renal tubular acidosis. Neurology 40:1761-1763

25. Moraes CT, DiMauro S. Zeviani M. Lombes A, Shanske S Miranda AF, Nakase H, Bonilla E, Werneck LC. Servidei S. Nonaka I. Schmidt B, Schotland DL, Zupang M. DeVivo DC, Schon EA, Rowland LP 1989 Mitochondrial DNA deletions in progressive external ophthalmoplegia and Kearns-Sayre syndrome. N Engl J Med 320:1293-1299

26. Larsson NG, Holme E, Kristiansson B, Oldfors A. Tulinius M 1990 Progressive increase of the mutated mitochondrial DNA fraction in Kearns-Sayre syndrome. Pediatr Res 28:131-136

27. McShane MA. Hammans SR, Sweeney M, Holt IJ, Beattie TJ, Brett EM, Harding AE 1991 Pcarson syndrome and mitochondrial encephalomyopathy in a patient with a deletion of mtDNA. Am J Hum Genet 48:39-42

28. Wallace DC 1987 Maternal genes: mitochondrial diseases. Birth Defects $23: 137-190$ 